\title{
MEMPERKUAT ISLAM MODERAT MELALUI METODE PEMBELAJARAN DEMOKRASI DI MADRASAH IBTIDAIYAH
}

\section{Roihan Imamul M1, Ujon Sujono ${ }^{2}$, Yuri A Fathallah ${ }^{3}$}

STAI KH. Abdul Kabier ${ }^{1}$, STAI KH. Abdul Kabier ${ }^{2}$, STAI KH. Abdul Kabier ${ }^{3}$ Email : roihanimamu188@gmail.com ${ }^{1}$, ujonsujono24@gmail.com², yurinefal@gmail.com ${ }^{3}$

\begin{abstract}
This paper aims to promote the implementation of the concept of strengthening moderate Islam through democratic learning in Islamic elementary schools. The ease of internet access and remote communication, as the effect of globalization in the field of technology, can be used to gain any information needed, including the Islamic knowledge that can be freely learned without teachers. A literature study was employed to describe the data related to the internalization of moderate Islam and democratic learning. The findings demonstrate that moderate Islam (tawasuth) is a life principle that upholds justice in social life. The values of moderate Islam can be internalized in the school curriculum as a reinforcement starting from the elementary school level through implementing democratic learning. This application can be carried out through various methods such as discussion, question and answer, group work, and simulation. The implementation of democratic learning encourages communicative relationships between teachers and students, fosters friendship, and enhances the value of 'ukhuwah' (good relations). Furthermore, these methods emphasize studentcentered learning. This study also illustrates that democratic learning provides a wide array of opportunities for students to creatively and critically express their ideas and thoughts in their own learning styles.
\end{abstract}

Keywords : Moderate Islam, Democratic Learning, Islamic Elementary School 
Abstrak : Tulisan ini bertujuan untuk mempromosikan implementasi konsep penguatan Islam moderat melalui metode pembelajaran demokrasi di madrasah ibtidaiyah (MI). Mudahnya mengakses informasi dan berkomunikasi jarak jauh sebagai dampak globalisasi dalam bidang teknologi dapat dimanfaatkan untuk memperoleh informasi yang dibutuhkan termasuk pengetahuan agama yang bisa dipelajari dengan bebas tanpa bimbingan seorang guru. Penelitian ini merupakan studi literatur untuk mendeskripsikan data yang terkait dengan penanaman Islam moderat dan pembelajaran demokrasi. Hasil penelitian ini mendemonstrasikan bahwa Islam moderat (tawasuth) berintikan prinsip hidup yang menjunjung tinggi berlaku adil dalam kehidupan sosial. Nilai-nilai Islam moderat dapat diinternalisasikan di dalam kurikulum sekolah sebagai penguatan mulai jenjang MI melalui penerapan pembelajaran demokrasi. Penerapan tersebut dapat ditunjukkan melalui berbagai metode seperti diskusi, tanya jawab, kerja kelompok, dan simulasi. Implementasi metode pembelajaran demokratis mendorong adanya hubungan komunikatif antara pendidik dengan peserta didik, penanaman hubungan silaturahim, dan peningkatan nilai ukhuwah. Lebih lanjut, metode-metode tersebut menekankan pada pembelajaran yang berpusat pada siswa. Penelitian ini juga menggambarkan bahwa pembelajaran demokrasi memberikan kesempatan seluas-luasnya kepada peserta didik untuk mengekspresikan gagasan dan pikirannya secara kreatif dan kritis sesuai dengan gaya belajar yang dimiliki.

Kata Kunci : Islam Moderat, Pembelajaran Demokrasi, Madrasah Ibtidaiyah. 


\section{PENDAHULUAN}

Sikap keras dan kasar (radikal) sebagian kelompok umat Islam terhadap umat Islam lain atau pada agama lain mencerminkan sikap yang tidak berprikemanusiaan. Mereka merasa paling benar karena doktrin yang mendarah daging dan membuat mereka bersikukuh untuk menegakkan kebenaran versi mereka. Berdasarkan hasil survei Wahid Foundation bersama Lingkar Survei Indonesia pada 2019, diungkapkan bahwa 11 juta dari 150 juta penduduk muslim Indonesia siap melakukan tindakan radikal. Jumlah tersebut mencapai 7,7 persen dari total penduduk muslim Indonesia. Sementara itu, 600 ribu atau 0,4 persen penduduk muslim Indonesia pernah melakukan tindakan radikal (Tempo.co, 2017). Lebih mengejutkan lagi, Lestari (2016) menyebutkan bahwa anakanak di sekolah tingkat dasar dan menengah bahkan taman kanak-kanak berisiko terpapar ajaran intoleransi dan radikalisme.

Fenomena-fenomena di atas menunjukkan salah satu indikator dari sikap intoleran dalam menghadapi sebuah perbedaan; padahal sebenarnya perbedaan merupakan keniscayaan/sunatullah. Pola berpikir setiap manusia pasti berbeda, tetapi bagaimana perbedaan itu menjadikan satu sama lain saling mengerti. Miftahuddin (2010: 3) berpendapat bahwa sumber rujukan agama Islam ialah sama, yaitu: al-Quran dan al Hadits. Namun, fakta menunjukkan bahwa wajah Islam adalah tidak hanya satu. Ada berbagai golongan Islam yang terkadang mempunyai ciri khas tersendiri dalam praktik dan amaliah keagamaannya. Tampaknya, perbedaan itu sudah menjadi kewajaran, sunatullah, dan bahkan suatu rahmat. Dengan demikian, memoderasi pemikiran untuk mewujudkan Islam rahmatan lil alamin, Islam moderat, menjadi sebuah keniscayaan.

Paham Islam moderat dapat merujuk pada cara yang dilakukan para Walisongo dalam menyebarluaskan Islam di nusantara. Sikap tawassuth (moderat) berintikan pada prinsip hidup yang menjunjung tinggi keharusan berlaku adil dan lurus di tengah kehidupan bersama (Cholid, 2017: 69). Sikap inilah yang dijalani Walisongo dalam menyebarkan Islam di Pulau Jawa, Indonesia sehingga mendapatkan keberhasilan seperti sekarang. Berdasarkan fakta sejarah, dengan cara menoleransi tradisi lokal serta memodifikasinya ke dalam ajaran Islam dan tetap bersandar pada prinsip-prinsip Islam, Islam sebagai agama baru pada masa itu dapat diterima oleh para bangsawan serta mayoritas masyarakat Jawa di pesisir Utara (Mas'ud, 2006: 54-58).

Generasi pengusung Islam moderat selanjutnya dapat merujuk pada praktik keberagamaan yang antara lain dilakukan oleh dua organisasi keagamaan terbesar di Indonesia, yaitu: Nahdlatul Ulama dan Muhammadiyah. Ber-Islam dalam konteks Indonesia semacam ini lebih cocok diungkapkan dengan ber"Islam dalam bingkai keindonesiaan" (Ma'arif, 2009). Oleh karena itu, diperlukan peran lembaga pendidikan untuk menanamkan nilai-nilai Islam yang berlandaskan semangat keindonesiaan.

Lembaga pendidikan Islam memiliki tanggung jawab besar dalam menyebarluaskan Islam yang rahmatan lil 'alamin dan keberhasilan pendidikan merupakan hal yang sangat penting untuk membantu seseorang mencapai kesuksesannya dengan memiliki sikap moderat. Rohman (2017: 422) mengesakan bahwa lembaga pendidikan formal merupakan pilar yang sangat strategis untuk mentransfer nilai-nilai toleransi, moderasi, rasa hormat, dan empati serta untuk mengembangkan sikap tanpa kekerasan kepada siswa. Hal ini mengimplikasikan bahwa kepandaian tanpa pembentukan karakter yang baik hanya akan 
menghasilkan selembar ijazah semata, tetapi tidak diimbangi dengan budi pekerti yang luhur. Diperlukan usaha lebih dari lembaga pendidikan, termasuk madrasah ibtidaiyah, untuk menghadirkan metode pembelajaran yang diharapkan mampu mendorong penanaman nilai-nilai Islam moderat.

Pemilihan metode pembelajaran di madrasah ibtidaiyah (MI) menjadi salah satu kunci guru dalam mencapai tujuan yang diinginkan, bahkan ada ungkapan "at-thariqah ahammu mina-l-maddah". Ungkapan tersebut menunjukkan pentingnya penggunaan metode dalam pembelajaran. Metode pembelajaran demokrasi menjadi salah satu tawaran untuk mewujudkan generasi yang memiliki paham Islam moderat karena Islam dipahami sebagai 'moderat' dan 'toleran' serta sesuai dengan bawaan demokrasi (Umar, 2016: 399).

Pelibatan semua peserta didik dengan menekankan cara berfikir kreatif dan kritis dalam mengemukakan pendapat, ide, dan gagasan sesuai dengan gaya belajar yang dimiliki merupakan gambaran metode pembelajaran demokrasi sebagai usaha dalam menumbuhkembangkan kesadaran dalam beragama (Islam) yang moderat. Berdasarkan isu-isu yang dipaparkan di atas, artikel ini mencoba untuk menginvestigasi implementasi konsep penguatan Islam moderat melalui metode pembelajaran demokrasi yang dilaksanakan di Madrasah Ibtidaiyah (MI).

\section{METODE PENELITIAN}

Tulisan ini menggunakan metode deskriptif analisis yang di dukung oleh data yang di proleh melalui Library research atau penelitian keperpustakaan. Library research atau penelitian keperpustakaan ini, penulis melakukan dengan mempelajari, menelaah dan mengkaji Al-Qur'an, buku-buku, jurnal, koran, dan lain sebagainya yang erat kaitannya dengan masalah yang di bahas. Pendekatan. penelitian ini menggunakan pendekatan filosofis, yaitu berusaha memecahkan masalah dengan usaha pemikiran mendalam dan sistematis. Terkait dengan penilitian ini penulis berusaha meneliti dengan mengikuti cara dan alur pikiran tokoh yang di teliti hingga diproleh dasar pemikiran pengarang dalam penulisan karyanya.

\section{HASIL DAN PEMBAHASAN}

\section{Internalisasi Nilai-Nilai Islam Moderat di Madrasah Ibtidaiyah}

Istilah 'Islam moderat' harus dipahami oleh umat Islam. Bakir \& Othman (2017: 22) mendefinisikan Islam moderat sebagai indera konseptual 'tengah' dari tindakan keseimbangan seperti pendekatan yang adil dan sederhana dan keadaan tindakan keseimbangan yang nol dari ekstrim dan fanatik dalam setiap aspek kehidupan manusia. Sementara itu, Yaakub \& Othman (2016: 62) menggarisbawahi bahwa kata-kata 'Islam moderat' (wasatiyyah) adalah istilah terminologis yang mewakili kerangka kerja konseptual yang hanya diberikan kepada umat Islam seperti yang dinyatakan dalam al-Qur'an, Surah al-Baqarah (2: 143), sebagaimana diterjemahkan oleh Kementerian Agama RI (2013):

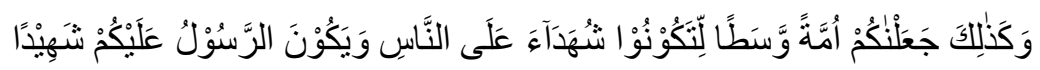

Artinya :"Dan demikian (pula) Kami menjadikan kamu (umat Islam) ummatan wasathan (umat yang adil dan pilihan) agar kamu menjadi saksi atas (perbuatan manusia) dan agar Rasul (Muhammad) menjadi saksi atas (perbuatan) kamu..." 
Surah al-Baqarah Ayat 143 tersebut menunjukkan bahwa terdapat istilah ummatan wasathan. Kata wasath berarti tengah, pertengahan, moderat, jalan tengah, seimbang antara dua kutub atau dua ekstrim (kanan dan kiri). AlMunawwir menyatakan kata wasathan artinya tengah-tengah, sedangkan Sya'bi dalam kamus alQalam mengartikan wasathan sebagai pertengahan (Cholid, 2017: 74). Definisi ini mengindikasikan bahwa ummatan washatan adalah umat yang bersikap, berpikiran, dan berperilaku moderasi, adil, dan proporsional antara kepentingan material dan spiritual, ketuhanan dan kemanusiaan, masa lalu dan masa depan, akal dan wahyu, individu dan kelompok, realisme dan idealisme, serta orientasi duniawi dan ukhrawi.

Sikap tawasuth yang berintikan kepada prinsip hidup yang menjunjung tinggi keharusan adil dan lurus di tengah-tengah kehidupan bersama, termasuk pada madrasah ibtidaiyah, bertindak lurus dan selalu bersifat membangun serta menghindari segala bentuk pendekatan yang bersikap tatharruf (ekstrim) (Nurcholis, 2011: 96). Penerapan sikap tawasuth (dengan berbagai dimensinya) bukan berarti bersifat serba boleh (kompromistik) dengan mencampuradukkan semua unsur (sinkretisme), juga bukan mengucilkan diri dan menolak pertemuan dengan unsur lain. Hal ini sejalan dengan Siddiq, 2005: 62-63) yang menyatakan bahwa prinsip dan karakter tawasuth yang sudah menjadi karakter Islam ini harus diterapkan dalam segala bidang, termasuk lembaga pendidikan, supaya agama Islam dan sikap serta tingkah laku umat Islam selalu menjadi saksi dan pengukur kebenaran bagi semua sikap dan tingkah laku manusia pada umumnya.

Kaitannya dengan implementasi nilai-nilai Islam moderat di madrasah ibtidaiyah, manifestasi prinsip dan karakter moderat harus dipertahankan, dipelihara dan, dikembangkan sebaik-baiknya. Hal ini mengonfirmasi apa yang dijelaskan oleh Cholid (2017: 76-81) bahwa beberapa prinsip dan karakter moderat (tawasuth) dalam ajaran Islam meliputi 1) moderat dalam bidang aqidah, 2) moderat dalam syariah, 3) moderat dalam bidang tasawuf dan akhlak, 4) moderat dalam bidang pergaulan (mu'asyarah), 5) moderat dalam bidang kehidupan bernegara, dan 6) moderat dalam bidang kebudayaan. Prinsip dan karakter Islam moderat perlu ditanamkan sejak kepada peserta didik di tingkat madrasah ibtidaiyah agar menjadi generasi masa depan yang berkarakter Islam rahmatan lil 'alamin. Hal ini menyetujui apa yang ditegaskan oleh Wani, Abdullah, \& Chang (2015: 653-654) bahwa keragaman adalah kecenderungan alami yang harus diterima oleh semua manusia. Orang dengan perilaku yang saling bertentangan adalah mereka yang tidak memiliki sikap moderasi, toleransi, akomodasi, dan kerja sama. Selanjutnya, melalui dialog peradaban, orang-orang dari berbagai filosofi dan ideologi dapat meminimalkan dan mengurangi perbedaan mereka.

\section{Metode Pembelajaran Demokrasi di Madrasah Ibtidaiyah}

Metode pembelajaran merupakan cara atau teknik yang digunakan guru dalam menyampaikan bahan ajar pada proses pembelajaran, baik secara individual atau kelompok. Salamun dalam Sudrajat (2009: 7) menyatakan bahwa metode pembelajaran adalah sebuah cara yang berbeda untuk mencapai hasil pembelajaran yang berbeda di bawah kondisi yang berbeda pula. Hal ini berarti pemilihan metode pembelajaran harus disesuaikan dengan kondisi pembelajaran dan hasil pembelajaran yang ingin dicapai. 
Adapun syarat-syarat yang harus diperhatikan oleh guru dalam penggunaan metode pembelajaran ialah 1) metode yang dipergunakan harus dapat membangkitkan motif, minat, atau gairah belajar peserta didik, 2) metode yang digunakan dapat merangsang keinginan peserta didik untuk belajar lebih lanjut, 3) metode yang digunakan harus dapat memberikan kesempatan bagi peserta didik untuk mewujudkan hasil karya, 4) metode yang digunakan harus dapat menjamin perkembangan kegiatan kepribadian peserta didik, 5) metode yang digunakan harus dapat mendidik murid dalam teknik belajar sendiri dan cara memperoleh pengetahuan melalui usaha pribadi, dan 6) metode yang digunakan harus dapat menanamkan dan mengembangkan nilai-nilai dan sikap peserta didik dalam kehidupan sehari-hari(Sabri, 2005: 52-53). Syarat-syarat ini dapat diterapkan dalam metode pembelajaran demokrasi.

Metode pembelajaran demokrasi menekankan bahwa apa yang harus terjadi ialah bagaimana pola-pola demokrasi dalam proses pembelajaran terlaksana. Dengan kata lain pembelajaran demokrasi adalah pembelajaran yang direncanakan dengan konsep yang memungkinkan praktik dari proses pembelajaran demokratis itu terlaksana, seperti memberikan kesempatan kepada peserta didik seluas-luasnya untuk belajar, berfikir, bekerja, dan membiarkan mereka bergerak membangun keilmuannya, sehingga peserta didik memiliki peluang yang besar untuk belajar memberanikan diri membuka wawasannya. Hal ini konsisten dengan apa yang dijelaskan oleh Rosyada (2004: 19-20) bahwa terpenuhinya misi pendidikan sangat bergantung pada kemampuan guru untuk menanamkan setting demokrasi pada peserta didik, dengan memberikan kesempatan seluas-luasnya pada peserta didik untuk belajar. Hal ini mengimplikasikan bagaimana menciptakan sekolah menjadi tempat yang nyaman bagi peserta didik untuk semaksimal mungkin mereka belajar.

Lebih lanjut lagi, pembelajaran demokratis adalah pembelajaran yang mengedepankan hal-hal yang bernuansa demokratis yaitu suasana pembelajaran yang saling menghargai adanya kebebasan berpendapat dan mengungkapkan gagasan, serta keterlibatan peserta didik dalam berbagai aktivitas (Wahid, 2010). Menurut Sugarda Purwakawatja yang dikutip oleh Ramayulis (2006: 333) mengatakan bahwa demokrasi pendidikan adalah pengajaran pendidikan yang semua anggota masyarakat mendapatkan pendidikan dan pengajaran yang adil. Dengan kata lain, metode pembelajaran demokratis adalah pembelajaran yang di dalamnya terdapat interaksi antara guru dengan peserta didik dengan suasana pembelajaran yang saling menghargai dan memperhatikan semua inisiatif, pemikiran, gagasan, ide, kreativitas, dan karya peserta didik sehingga dapat mengondisikan peserta didik untuk lebih mengenal dan mengungkapkan kehidupannya secara nyata dengan sikap kritis yang dimilikinya.

Terkait dengan hal itu, kita bisa membuka paradigma berpikir kita bahwasanya tujuan hakiki peserta didik belajar ialah tidak hanya untuk menambah khazanah keilmuan semata, tetapi lebih jauh dari itu, agar mereka mampu merasakan kehidupannya secara nyata dari pengalaman belajar yang telah didapatkannya sehingga pada akhirnya mampu menyelesaikan persoalan kehidupannya satu saat nanti. Oleh karenanya, seorang guru dituntut benar-benar mampu mengembangkan metode pembelajaran yang tepat agar tercapai tujuan pembelajaran yang diharapkan. Hal ini relevan dengan dinyatakan oleh Christopel \& Kuntoro (2016: 15) bahwa nilai-nilai demokrasi hendaknya dapat diaktualiasikan dalam kehidupan nyata melalui suatu transformasi, khususnya 
dalam bidang melalui pendidikan, yang diaplikasikan dengan penggunaan metode pembelajaran demokrasi.

Suasana yang demokratis dalam kelas juga akan banyak memberikan kesempatan kepada peserta didik untuk berlatih mewujudkan dan mengambangkan hak atau kemampuannya serta kewajibannya. Suasana yang demokratis dapat dikembangkan dalam proses pembelajaran melalui hubungan antara guru dengan peserta didik. Tambahan pula, dalam suasana demokratis tersebut, semua pihak memperoleh penghargaan sesuai dengan potensi dan prestasinya masing-masing sehingga dapat memupuk rasa percaya diri dan dapat berkreasi sesuai dengan kemampuannya tersebut.

Dalam pembelajaran, peserta didik diposisikan sebagai subjek belajar, bukan sebagai objek belajar yang diibaratkan seperti halnya botol kosong yang siap untuk diisi apapun, bukan pula seperti halnya kertas putih yang siap ditulisi apapun oleh gurunya. Akan tetapi, dengan posisinya sebagai subjek belajar maka posisi guru hanya sebatas fasilitator dengan memaksimalkan peran peserta didik dalam proses pembelajaran. Ini mengafirmasi apa yang dipaparkan oleh Taniredja \& Abduh (2016: 331) bahwa guru atau dosen perlu menerapkan pendidikan demokrasi melalui pembelajaran di dalam kelas dengan memainkan peran sebagai fasilitator atau role model kepada peserta didik sehingga dapat memberikan teladan yang baik. Hal ini mendemonstrasikan bahwa metode pembelajaran demokratis menjadi sangat urgen untuk mengawal tumbuh kembangnya seluruh potensi yang dimiliki peserta didik sebagai subjek belajar yang hakiki.

\section{Penguatan Islam Moderat Melalui Pembelajaran Demokrasi di Madrasah Ibtidaiyah}

Setiap anak memiliki struktur kognitif yang disebut schemata, yaitu: sistem konsep yang ada dalam pikiran sebagai hasil pemahaman terhadap objek yang ada dalam lingkungannya. Pemahaman tentang objek tersebut berlangsung melalui proses asimilasi (proses menghubungkan objek dengan konsep yang sudah ada dalam pikiran) dan proses akomodasi (proses memanfaatkan konsepkonsep dalam pikiran untuk menafsirkan objek). Kedua prosestersebut jika berlangsung terus menerus akan membuat pengetahuan lama dan pengetahuan baru menjadi seimbang. Husamah (2016: 81) menegaskan bahwa dengan cara seperti itu secara bertahap anak dapat membangun pengetahuan melalui interaksi dengan lingkungannya. Hal ini mendemonstrasikan bahwa perilaku belajar anak sangat dipengaruhi oleh aspek-aspek dari dalam dirinya dan lingkungannya. Kedua hal tersebut tidak mungkin dipisahkan karena memang proses belajar terjadi dalam konteks interaksi diri anak dengan lingkungannya.

Lebih lanjut, Husamah (2016: 82) menjelaskan bahwa anak usia sekolah dasar setingkat madrasah ibtidaiyah (MI) berada pada tahapan operasional konkret. Pada rentang usia sekolah dasar tersebut, anak mulai menunjukkan perilaku-perilaku belajar di antaranya: 1) mulai memandang dunia secara objektif, bergeser dari satu aspek situasi ke aspek lain secara reflektif dan memandang unsur-unsur secara serentak, 2) mulai berpikir secara operasional, 3) mempergunakan cara berpikir operasional untuk mengklasifikasikan bendabenda, 4) membentuk dan mempergunakan keterhubungan aturan-aturan, prinsip ilmiah sederhana, dan mempergunakan hubungan sebab akibat, dan 5) memahami konsep substansi, volume zat cair, panjang, lebar, luas, dan berat.

Memperhatikan tahapan perkembangan berpikir tersebut, kecenderungan belajar anak usia sekolah dasar memiliki tiga karakteristik, yaitu: konkret, 
integratif, dan hierarkis. Karakteristik pertama mengilustrasikan bahwa proses belajar beranjak dari halhal yang konkret; dapat dilihat, didengar, dibaui, diraba, dan diotak-atik, dengan memanfaatkan lingkungan sebagai sumber belajar. Dengan demikian, hasil belajarnya menjadi lebih bermakna dan bernilai sebab peserta didik dihadapkan dengan peristiwa dan keadaan yang sebenarnya, keadaan yang alami, lebih nyata, lebih faktual, lebih bermakna, dan kebenarannya dapat dipertanggungjawabkan. Ciri kedua memaparkan bahwa usia anak sekolah MI memandang sesuatu yang dipelajari sebagai suatu keutuhan. Mereka belum mampu memilah-milah konsep dari berbagai disiplin ilmu. Hal ini melukiskan cara berpikir anak yang deduktif yakni dari hal umum menuju hal yang lebih khusus (bagian-bagian). Sementara itu, karakteristik ketiga menunjukkan cara anak belajar berkembang secara bertahap mulai dari hal-hal yang sederhana ke hal-hal yang lebih kompleks. Sehubungan dengan hal tersebut, perlu diperhatikan mengenai urutan logis, keterkaitan antar materi, cakupan keluasan serta kedalaman materi (Husamah, 2016: 83-87).

Berdasarkan hal di atas, sebagai upaya untuk keluar dari pembelajaran yang bersifat membelenggu menuju pada pembelajaran yang membebaskan atau demokratis dibutuhkan keterbukaan dan sikap lapang dada dari guru untuk memberikan kesempatan seluas-luasnya kepada peserta didik guna mengekspresikan gagasan dan pikirannya. Dalam pembelajaran demokratis ini, tidak ada subjek yang membebaskan atau objek yang dibebaskan karena tidak ada dikotomi antara subjek dan objek. Pendidik dan peserta didik sama-sama sebagai subjek dan objek sekaligus. Hal ini mengindikasikan bahwa keduanya memungkinkan untuk saling take and give (menerima dan memberi).

Metode pembelajaran yang demokratis tidak bertujuan menciptakan manusia siap kerja, tetapi membentuk manusia matang dan berwatak yang siap belajar terus, siap menciptakan lapangan kerja dan siap mengadakan transformasi sosial karena sudah lebih dahulu mengalami transformasi diri lewat pendidikan. Pendidikan yang demokratis merupakan sebuah karya pembentukan manusia merdeka yang human, matang, berbudaya, dan bertanggung jawab sehingga wajib dikelola oleh birokrat pendidikan yang demokratis, human, matang serta memiliki compassion dan passion pada manusia muda. Hal ini mengonfirmasi pendapat Rosyid (2006: 103) yang memaparkan bahwa tujuan yang diharapkan dengan adanya pembelajaran demokratis ialah: 1) peserta didik mampu melaksanakan pola belajar demokratis, 2) menjadikan belajar demokratis sebagai strategi baru sekaligus mentradisikannya dalm proses pembelajaran bagi pendidik ataupun calon pendidik, dan 3) menemukan berbagai konsepsi yang serba baru dalam mensosialisasikan pembelajaran demokratis.

Deskripsi di atas mengilustrasikan bahwa metode pembelajaran demokratis tidak hanya untuk menyiapkan peserta didik bagi kehidupan mereka nanti di masyarakat, melainkan madrasah juga harus menjadi masyarakat mini, tempat praktik demokrasi, sesuatu yang ada dalam bangunan masyarakat perlu diadakan secara nyata di madrasah. Dengan demikian, peserta didik dibiasakan dengan karakteristik kehidupan yang demokratis.

Untuk mewujudkan terciptanya metode pembelajaran demokratis, langkahlangkah yang dapat dilakukan antara lain: pertama, hindari indoktrinasi. Biarkan peserta didik aktif dalam bertanya, bersikap kritis terhadap apa yang dipelajarinya, dan mengungkapkan alternatif pandangannya yang berbeda dengan gurunya. Kedua, hindari paham bahwa hanya ada satu nilai saja yang benar. Guru 
tidak berpandangan bahwa apa yang disampaikannya adalah yang paling benar. Seharusnya sikap yang dikembangkan adalah memberi peluang yang cukup lapang akan hadirnya gagasan alternatif dan kreatif terhadap penyelesaian suatu persoala. Ketiga, berikan anak kebebasan untuk berbicara. Peserta didik mesti dibiasakan untuk berbicara. Peserta didik dibiasakan dalam kontek penyampaian gagasan serta proses membangun dan meneguhkan sebuah pengertian harus diberi ruang yang seluas-luasnya. Keempat, berikan peluang bahwa peserta didik boleh berbuat salah. Kesalahan merupakan bagian penting dalam pemahaman. Guru dan peserta didik menelusuri bersama di mana terjadi kesalahan dan membantu meletakkannya dalam kerangka yang benar. Kelima, kembangkan cara berfikir ilmiah dan berfikir kritis. Dengan ini peserta didik diarahkan untuk tidak selalu mengiyakan apa yang telah dia terima, melainkan dapat memahami sebuah pengertian dan memahami mengapa harus demikian. Keenam, berikan kesempatan yang luas kepada peserta didik untuk bermimpi dan berfantasi. Kesempatan bermimpi dan berfantasi bagi peserta didik menjadikan dirinya memiliki waktu untuk berandai-andai tentang sesuatu yang menjadi keinginannya. Sehingga peserta didik dapat mencari inspirasi untuk mewujudkan rasa ingin tahunya (Departemen Pendidikan Nasional, 2006: 17-18).

Berdasarkan beberapa langkah di atas, ada beberapa metode yang akan mendukung terlaksananya pembelajaran yang demokratis di MI supaya peserta didik tidak terbelenggu dan lebih aktif dalam proses belajar mengajar di kelas. Metode pertama ialah diskusi. Metode diskusi adalah suatu cara yang dapat dipakai oleh seorang guru di kelas dengan tujuan dapat memecahkan suatu masalah berdasarkan pendapat para peserta didik. Metode ini mempunyai beberapa manfaat yang bisa diambil, antara lain: a) suasana kelas lebih hidup karena peserta didik mengarahkan perhatian atau pikirannya kepada masalah yang sedang didiskusikan, b) menaikkan prestasi kepribadian individu seperti, toleransi, berfikir kritis, demokratis, sistematis, sabar dan sebagainya, c) simpulan hasil diskusi mudah dipahami peserta didik karena mereka mengikuti proses berfikir sebelum sampai kepada suatu kesimpulan, dan d) tidak terjebak ke dalam pikiran individu yang kadang-kadang salah, penuh prasangka, dan sempit. Dengan diskusi, seseorang dapat mempertimbangkan alasan-alasan/pikiran-pikiran orang lain (Arief, 2002: 148-149). Hal ini menggambarkan bahwa dengan adanya metode diskusi, peserta didik bisa menjadi lebih mandiri dalam memecahkan suatu permasalahan dan lebih bisa menghargai pendapat orang lain sehingga akan tertanam sikap demokratis dari diri peserta didik sejak dini.

Metode kedua ialah tanya jawab. Metode ini memungkinkan terjadinya two-way communication (komunikasi dua arah) karena pada saat yang sama terjadi dialog antara guru dan peserta didik; guru bertanya peserta didik menjawab atau peserta didik bertanya guru menjawab. Metode tanya jawab memiliki beberapa tujuan yang dapat dicapai, antara lain: a) mengecek dan mengetahi sampai sejauh mana materi pelajaran yang telah dikuasai oleh peserta didik, b) merangsang peserta didik berfikir, c) memberi kesempatan pada peserta didik untuk mengajukan masalah yang belum dipahami, d) memotivasi peserta didik untuk menimbulkan sikap kompetisi dalam belajar dan e) melatih peserta didik untuk berpikir dan berbicara secara sistematis berdasarkan pemikiran orisinil (Majid, 2008: 210). Hal ini mendemonstrasikan bahwa dengan adanya penerapan metode tanya jawab, guru memberikan kesempatan kepada peserta didik untuk langsung bisa menanyakan hal yang belum dipahaminya. Dengan demikian, 
peserta didik merasa bahwa semua dianggap sama dihadapan gurunya, karena guru memberikan kesempatan yang sama kepada semua peserta didik untuk menanyakan masing-masing hal yang belum diketahuinya.

Metode ketiga ialah kerja kelompok. Metode ini mengandung pengertian bahwa peserta didik dalam satu kelas dipandang sebagai satu kesatuan (kelompok) tersendiri ataupun dibagi atas kelompok-kelompok kecil (subbab kelompok) (Majid 2008: 211). Metode kerja kelompok memiliki beberapa keuntungan, antara lain: 1) melatih dan menumbuh rasa kebersamaan, toleransi dalam sikap dan perbuatan, 2) menumbuhkan rasa ingin maju dan mendorong anggota kelompok untuk tampil sebagai kelompok yang terbaik, dan (3) timbul rasa kesetiakawanan sosial antara kelompok yang dilandasi motivasi kerja sama untuk kepentingan dan kebaikan bersama (Arief, 2002: 112). Hal ini melukiskan bahwa dengan adanya penerapan metode kerja kelompok, peserta didik akan merasa memiliki sifat toleransi tinggi, saling tolong-menolong dalam memecahkan masalah pada kelompoknya, dan saling menghargai pendapat antar satu kelompok untuk dapat menemukan suatu simpulan.

Metode keempat ialah simulasi. Metode ini dapat dijadikan sebagai bekal bagi peserta didik dalam menghadapi situasi yang sebenarnya kelak, baik dalam kehidupan keluarga, masyarakat, maupun menghadapi dunia kerja. Penggunaan metode simulasi juga memilki keuntungan, antara lain: 1) mengembangkan kreativitas peserta didik, 2) dapat memupuk keberanian dan kepercayaan diri peserta didik, dan 3) memperkaya pengetahuan, sikap, dan ketrampilan yang diperlukan dalam menghadapi berbagai situasi sosial yang problematis (Majid, 2008: 207-208). Penerapan metode simulasi diharapkan dapat menjadikan peserta didik lebih berani untuk maju dan tampil dalam melakukan suatu keterampilan tertentu seperti dalam mensimulasikan gerakan thawaf pada materi haji dalam mata pelajaran pendidikan agama Islam.

Adanya pembelajaran demokratis, pendidik tidak sekedar memberikan informasi, memberikan tes dan kemudian memberikan nilai, tetapi pendidik berusaha memahami apa yang dipikirkan dan dipahami oleh peserta didik. Hal ini sejalan dengan yang disampaikan oleh Zamroni (2001: 189) bahwa di samping memahami materi, pendidik juga berusaha memiliki pemahaman yang mendalam tentang diri peserta didik, serta mengembangkan hubungan yang akrab dengan mereka sehingga dapat menciptakan suasana di mana peserta didik berusaha mencapai prestasi secara optimal.

Prinsip belajar anak didik aktif dalam metode pembelajaran demokratis ini lebih memberikan tekanan pada kegiatan peserta didik yang disebut sebagai pengajaran yang berpusat pada peserta didik (student-centered) sangat ditonjolkan (Djamarah \& Zain, 2003: 84-85). Metode pembelajaran demokratis memandang bahwa anak didik memiliki kebebasan dalam mengekspresikan dirinya secara langsung, baik dengan tindakan maupun dengan gerakan, selama mereka tidak melanggar kaidah-kaidah dan nilai-nilai yang telah disepakati bersama. Hal ini konsisten dengan apa yang dinyatakan oleh Khalifah \& Quthub (2009: 55) bahwa dalam metode pembelajaran demokratis, semua peserta didik berhak dan memiliki kebebasan untuk mengekspresikan kebosanannya, kemarahannya, atau ketidaksenangannya terhadap materi pelajaran. Kebebasan berekspresi ini dianggap sebagai jaminan untuk kebaikan perilaku dan kedisiplinannya di bawah naungan kaidah-kaidah yang telah ditetapkan oleh kelompok mereka sendiri. Hal ini mengindikasikan bahwa dengan kondisi seperti itu, anak didik dapat 
mengembangkan potensi-potensi yang dimilikinya dan memberikan kemungkinan bagi mereka untuk meningkatkan kemandirian belajar sehingga akan menjadi anak didik yang kritis, kreatif, dan inovatif dalam belajar yang tidak selalu menggantungkan kepada pengajar, tetapi dengan selalu berlatih.

Tambahan lagi, Khalifah \& Quthub (2009: 334) mendeskripsikan bahwa metode pembelajaran demokratis memiliki beberapa prinsip dalam pendidikan, prinsip-prinsip demokrasi tersebut antara lain: 1) kebebasan dalam menuangkan ilmu, 2) penghormatan terhadap eksistensi manusia, 3) persamaan, 4) keadilan hukum dan 5) musyawarah mufakat. Penerapan prinsip-prinsip pendidikan tersebut memerlukan waktu yang cukup panjang dan proses yang berkelanjutan. Dengan demikian, prinsip-prinsip itu ketika sudah diturunkan dalam konsep yang lebih sederhana cenderung dapat berubah sesuai tuntunan dan perkembangan. Oleh karenanya, harus dipahami bahwa konsep demokrasi tidak dapat dirumuskan sekali untuk selama-lamanya sebab nilai-nilai itu tumbuh dalam proses yang berkelanjutan.

Menariknya, impelementasi dari metode pembelajaran demokratis memiliki beberapa keuntungan yang dapat diperoleh, antara lain:

1. Hubungan komunikatif antara pendidik dengan peserta didik yang berimbas pada kemudahan pemahaman dalam pembelajaran. Dengan hubungan yang sealur (komunikatif) dalam proses pembelajaran antara guru dengan peserta didik maka kekhawatiran munculnya akses negatif imbas dari aktifitas pembelajaran dapat diantisipasi sedini mungkin, misalnya munculnya mispersepsi, miskomunikasi, dan ekses negatif lainnya terutama hubungannya dengan karakter pendidik dan peserta didik yang bernuansa negatif;

2. Penanaman nilai silaturrahim karena hubungan yang linier. Dengan terkondisinya nuansa silaturrahim antara guru dan peserta didik maka harapan ideal menuju terwujudnya pembelajaran demokratis sedikit terbuka jika dibandingkan dengan terciptanya hubungan yang tidak harmonis, tidak linier, dan konfrontatif, mengingat konsepsi silaturrahim adalah konsepsi islami yang perlu mendapatkan perhatian khususnya dalam pelaksanaan pendidikan. Karena dengan silaturrahim menipiskan angan-angan negatif, kecurigaan, dan persepsi lainnya yang mengganjal proses pendidikan, hlm itu telah diantisipasi dengan adanya jalinan;

3. terjadinya nilai ukhuwah. Nilai ukhuwah dapat terbentuk jika hubungan komunikatif antara pendidik dan penanaman nilai silaturrahim telah menjadi bagian dari kehidupannya bahkan menjadi aktifitas riil (Rosyid, 2006: 164165).

\section{KESIMPULAN}

Penelitian ini menyoroti penguatan Islam moderat yang diinternalisasikan dengan metode pembelajaran demokrasi di MI cukup mendesak untuk diimplementasikan di dalam kelas, setidaknya didasarkan pada: pertama, bahwa prinsip Islam sebagai agama yang memberikan keamanan, kenyamanan, ketenangan dan ketenteraman bagi semua makhluknya. Tidak ada satupun ajaran di dalamnya yang mengajarkan kepada umatnya untuk membenci dan melukai makhluk lain. Kalaupun ada, itu adalah bagian kecil dari salah satu upaya pemecahan masalah yang dilakukan umatnya dan bukan ajarannya. Kitab suci alQur'an dan Hadits diyakini oleh umat Islam sebagai sumber utama dalam memecahkan semua persoalan yang ada. Keyakinan ini adakalanya bisa menjadi 
obat penenang dan bisa juga menjadi alasan untuk merugikan pihak lain, semua itu bergantung dari umatnya dalam memahami teks kitab suci ataupun sunah Nabi. Kedua, pemahaman agama yang radikal akan menimbulkan masalah sehingga pemahaman agama yang moderat sangat penting untuk menangkal radikalisme. Agama harus memberikan penguatan terhadap masalah yang ada baik politik, kebangsaan, dan kenegaraan.

Ketiga, kompleksnya kehidupan yang dihadapi peserta didik setelah lulus menuntut mereka mampu menyesuaikan diri. Prinsip belajar yang relevan adalah belajar untuk bagaimana belajar (learning how to learn). Hal ini berarti bahwa di kelas, target pembelajaran bukan sekadar penguasaan materi, melainkan peserta didik juga harus mampu belajar bagaimana belajar memecahkan masalahnya. Ini bisa terjadi apabila dalam kegiatan pembelajaran peserta didik telah dibiasakan untuk berpikir sendiri, berani berpendapat, dan berani bereksperiman. Keempat, kenyataan bahwa pendidik atau guru bukan lagi satu-satunya sumber belajar. Dalam era globalisasi informasi sekarang, tidak bisa dipungkiri bahwa akses terhadap berbagi sumber informasi menjadi begitu luas dan mudah bahkan murah, seperti halnya televisi, radio, buku, koran, majalah, dan internet. Saat berada di kelas, peserta didik telah memiliki seperangkat pengalaman, pengetahuan dan informasi. Semua ini sesuai dengan bahan pelajaran, tetapi bisa juga berseberangan. Metode pembelajaran demokratis memungkinkan terjadinya proses dialog yang berujung pada pencapaian tujuan instruksional yang ditetapkan. Tanpa demokrasi di kelas, guru akan menjadi penguasa tunggal yang tidak dapat diganggu gugat. Peserta didik terkekang dan pada akhirnya, potensi kreativitas peserta didik menjadi statis. Kelima, dalam konteks metode pembelajaran demokrasi, sebagai bagian dari anggota masyarakat, peserta didik hendaknya sejak dini telah dibiasakan bersikap demokratis bebas berpendapat, tetapi tetap sesuai dengan peraturan yang telah ditentukan. Ini bisa dimulai di kelas dalam bentuk kegiatan pembelajaran yang menekankan adanya sikap demokrasi.

\section{DAFTAR PUSTAKA}

Arief, A. (2002). Pengantar Ilmu dan Metodologi Pendidikan Islam. Jakarta: Ciputat Pers. Bakir, M., \& Othman, K. (2017).

A Conceptual Analysis of Wasatiyyah (Islamic Moderation-IM) from Islamic Knowledge Management (IKM) Perspective. Revelation and Science, $7(1), 21-31$.

Cholid, N. (2017). Pendidikan Ke-NU-an: Konsepsi Ahlussunah Waljamaah Annahdliyah. Semarang: Presisi Cipta Media.

Christopel, \& Kuntoro, S. A. (2016). pemahaman nilai-nilai demokrasi melalui metode inquiri pada pembelajaran pkn di sma negeri 1 gamping sleman. Harmoni Sosial: Jurnal Pendidikan IPS, 3 (1), 14-26.

Departemen Pendidikan Nasional. (2006). Teropong Pendidikan Kita. Jakarta: Pusat Informasi dan Humas Departemen Pendidikan Nasional.

Wahid, F. (2010). Pembelajaran demokratis pada bidang studi pendidikan agama islam di SMAN 29 Jakarta. Skripsi, Pendidikan Agama Islam, Fakultas Ilmu Tarbiyah dan Keguruan,

UIN Syarif hidayatullah Jakarta. Diperoleh pada 20 Desember 2017 dari http://repository.uinjkt.ac.id/dspace/handle/123456789/2138 
Husamah. (2016). Belajar dan Pembelajaran. Malang: Universitas Muhammadiyah Malang.

Kementerian Agama RI. (2013). Mushaf An-Nahdlah Al-Qur'an dan Terjemah. Jakarta: PT Hati Mas.

Lestari, S. (2016). Ketika paham radikal masuk ke ruang kelas sekolah. BBC News Indonesia. Diperoleh pada 26 Desember 2017

Ma'arif, A. S. (2009). Islam dalam Bingkai Keindonesiaan dan Kemanusiaan: Sebuah Refleksi Sejarah.Bandung: Mizan.

Khalifah, M., \& Quthub, U. (2009). Menjadi Guru yang Dirindu. Surakarta: Ziyad Visi Media.

Majid, A. (2008). Perencanaan Pembelajaran dalam Mengembangkan Standar Kompetensi Guru. Bandung: Remaja Rosdakarya.

Mas'ud, A. (2006). Dari Haramain ke Nusantara: Jejak Intelektual Arsitek Pesantren. Jakarta: Kencana.

Miftahuddin. (2010). Islam Moderat Konteks Indonesia Dalam Perspektif Historis. Mozaik: Jurnal Ilmu-ilmu Sosial dan Humaniora, 5(1), 1-20. https://doi.org/10.21831/moz.v5i1.4338

Rosyid, M. (2006). Strategi Pembelajaran Demokratis. Semarang: Unnes Press.

Nurcholis. (2011). Ahlussunnah Wal Jama'ah dan Nahdlatul Ulama. Tulungagung: PC NU Kabupaten Tulungagung. Ramayulis. (2008). Ilmu Pendidikan Islam. Jakarta: Kalam Mulia.

Rohman, A. (2017). Pesantren as a Basis for Internalization of Pluralistic Values for Preparing Democratic Citizens in a Diverse Society. Walisongo: Jurnal Penelitian Sosial Keagamaan, 25 (2), 419442.https://doi.org/10.21580/ws.25.2.1324

Rosyada, D. (2004). Paradigma Pendidikan Demokratis. Jakarta: Kencana.

Sabri, A. (2005). Strategi Belajar Mengajar Micro Teaching. Jakarta: Quantum Teaching.

Siddiq, A. (2005). Khitah Nahdliyah (Cet.III). Surabaya: Khalista-LTNU

Sudrajat, A. (2009). Pengertian Pendekatan, Strategi, Metode, Teknik dan Model Pembelajaran. Bandung:Sinar Baru Algensindo.

Djamarah, S. B., \& Zain, A. (2003). Strategi Belajar Mengajar. Jakarta: Rineka Cipta.

Taniredja, T., \& Abduh, M. (2016). Pengembangan Nilai-Nilai Demokratis Mahasiswa Melalui Pendidikan Kewarganegaraan. PKn Progresif, 11(2), 331-347.

Tempo.co. (2019). Yenny Wahid: 11 Juta Warga Siap Lakukan Tindakan Radikal. Diperoleh pada 26 Desember 2017 dari https://nasional.tempo.co/read/847391/yenny-wahid-11-juta-warga siaplakukan-tindakan-radikal/full\&view $=$ ok

Umar, A. R. M. (2016). A Genealogy of Moderate Islam: Governmentality and Discourses of Islam

in Indonesia's Foreign Policy. Studia Islamika, 23(3), 399- 433. DOI: 10.15408/sdi.v23i3.3157

Wani, H., Abdullah, R., \& Chang, L. (2015). An Islamic Perspective in Managing Religious Diversity. Religions, 6(2), 642-656. https://doi.org/10.3390/rel6020642 
Yaakub, M. B., \& Othman, K. (2016). A Textual Analysis For The Term "Wasatiyyah" (Islamic Moderation) In Selected Quranic Verses And Prophetic Tradition. Journal of Education and Social Sciences, 5, 61-68.

Zamroni. (2001). Pendidikan Untuk Demokrasi (Tantangan Menuju Civil Society). Yogyakarta: Bigraf Publishing. 